\title{
SINERGI IMPLEMENTASI ANTARA PENDIDIKAN AKIDAH DAN AKHLAK MENURUT HAMKA
}

\author{
Kasmali \\ SMA Hasyim Asy'ari Pekalongan \\ Jl. Dr. Wahidin 104 Pekalongan, Jawa Tengah \\ e-mail: kasmali91@gmail.com
}

\begin{abstract}
This article discusses the implementation of educational creed has a very close relationship with moral education. Creed became the foundation for the implementation of morals. Didsari deeds and djiwai by faith will lead to actions directed, planned, so awake from shirk. True and strong faith will bring a noble character and strong. All that is done is a reflection of the strength of faith, so that the behavior is done is correct behavior and sincere, reflecting the behavior of worship to God.
\end{abstract}

Abstrak: Artikel ini membahas tentang implementasi pendidikan akidah memiliki hubungan yang sangat erat dengan pendidikan akhlak. Akidah menjadi landasan bagi pelaksanaan akhlak. Perbuatan yang didsari dan djiwai oleh akidah akan menimbulkan perbuatan yang terarah, terencana, sehingga terjaga dari perbuatan syirik. Akidah yang benar dan kuat akan memunculkan akhlak yang mulia dan kuat. Semua yang dilakukan merupakan cerminan dari kekuatan akidah, sehingga perilaku yang dilakukan merupakan perilaku yang benar dan ikhlas, mencerminkan perilaku ibadah kepada Allah.

Keywords: akidah, akhlak, iman, syirik, pendidikan. 


\section{A. Pendahuluan}

Akidah merupakan sesuatu yang mengharuskan hati kita membenarkannya, yang membuat jiwa tenang tenteram kepada-Nya dan yang menjadi kepercaya-an yang bersih dari kebimbangan atau keraguan ${ }^{1}$, yang secara teknis merupakan kepercayaan, keyakinan, iman, yang terangkum dalam al-Arkan al-Iman, yaitu: iman kepada Allah SWT; iman kepada Malaikatmalaikat-Nya; iman kepada Kitab-kitabNya; iman kepada Rasul-rasulNya; iman kepada hari kiamat; dan iman kepada Qada' dan Qadar. ${ }^{2}$

Syariah merupakan peraturanperaturan yang diciptakan Allah SWT atau diciptakannya pokok-pokoknya supaya manusia berpegang kepadanya dalam berhubungan dengan Tuhan, dengan sesama manusia, dengan alam se-kitarnya dan berhubungan dengan kehidupannya. ${ }^{3}$

Akhlak merupakan suatu perangai (watak, tabiat) yang menetap kuat dalam jiwa seseorang dan merupakan sumber timbulnya perbuatan-perbuatan tertentu dari dirinya, secara mudah dan ringan, tanpa perlu dipikirkan atau direncanakan sebelumnya. ${ }^{4}$ Perbuatan yang dilakukan hanya sekali atau dua kali yang bukan merupakan kebiasaan,

${ }^{1}$ Hasan Al-Banna, Akidah Islam, terj. M. Hasan Baidaie, Bandung: Al- Ma'arif, 1983, h.9.

${ }^{2}$ Endang Saifuddin Anshari, Wawasan Islam, Pokok-pokok Pikiran tentang Paradigma dan Sistem Islam, Jakarta: Gema Insani, 2004,h. 44.

${ }^{3}$ Mahmud Syaltout, Islam sebagai Akidah \& Syariah, Jilid I terj. Bustami S. Gani dan B. Hamdani Ali, Jakarta: Bulan Bintang, 1983, h. 29

${ }^{4}$ Hadarah Rajab, Akhlak Sufi: Cermin Masa Depan Umat, Jakarta: Al-Mawardi Prima, 2004, h. 97. maka bukan menunjukkan akhlak. ${ }^{5}$ Karena adakalanya orang yang berwatak kikir namun kadang ia memberi sedekah/infak, hal itu terdorong oleh suatu kepentingan dirinya atau karena ingin dipuji.

Dalam artikel ini penulis akan mengkaji pendapat Hamka yang berkaitan dengan implementasi pendidikan akidah dan akhlak.

\section{B. Tentang Hamka}

Hamka akronim dari Haji Abdul Malik Karim Amrullah adalah seorang ulama dan penulis Islam Indonesia modern yang produktif. Hamka lahir pada 17 Februari 1908 bertepatan dengan 14 Muharram 1326 di desa kecil sungai Batang di Minangkabau, Sumatera Barat.

Ayahnya, Syaikh Dr. Abdul Karim Amrullah berasal dari keluarga ulama, merupakan seorang pelopor gerakan pembaharuan modernis. Ibunya bernama Siti Safiyah, ayah dari ibunya bernama Gelanggang gelar Bagindo nan Batuah yang mana ibunya dimasa muda terkenal sebagai guru tari, nyanyi dan juga pencak silat.

Pada tahun 1929 ketika usia 21 tahun Hamka dinikahkan dengan seorang anak perempuan bernama Siti Raham yang waktu itu baru berumur 15 tahun dan dikaruniai sepuluh orang anak: tujuh laki-laki dan tiga perempuan. Namun pada tahun 1972 istrinya meninggal dunia dan satu tahun delapan bulan setelah isteri pertamanya

${ }^{5}$ Ahmad Amin, Etika Islam (Ilmu Akhlak), terj. Farid Ma'ruf, Jakarta: Bulan Bintang, 1983, h. 63. 
meninggal pada tahun 1973 ia menikah lagi dengan Hj. Khadijah dari Cirebon. ${ }^{6}$

\section{Pendidikan dan Karir}

Sejak usia anak, Hamka menerima dasar-dasar agama dan membaca alQuran langsung dari ayahnya, dan ketika usia 6 tahun ia dibawa ayahnya ke Padang Panjang, dan pada usia 7 tahun ia dimasukkan ke sekolah desa namun hanya berlangsung selama 3 tahun. Pendidikan formalnya sangat sederhana, pada tahun 1916 sampai 1923 ia belajar agama pada lembaga pendidikan Diniyyah School di Padang Panjang, serta Sumatera Thawalib di Padang Panjang dan di Parabek. ${ }^{7}$

Mengutip pendapat Samsul Nizar bahwa, meskipun ia lebih banyak belajar secara otodidak, namun dengan daya penyerapannya yang luar biasa atas berbagai informasi keilmuan, menjadikannya sebagai sosok ilmuan yang telah ikut memperkaya khazanah kehidupan ilmu pengetahuan bangsa Indonesia.

Pengetahuan tentang Islam yang diperoleh langsung dari ayahnya, menambah keutuhan pandangan-pandangan Hamka tentang Islam. Bahkan ia mampu memahami 14 materi pelajaran yang telah dirumuskan oleh al-Suyuti dalam kitabnya Itmam al-Dirayah. Dasar pengetahuan tersebut bukan saja menyangkut persoalan materi inti ajaran Islam, akan tetapi juga metode-metode yang digunakan untuk memahami kesemua materi tersebut dan kemudian menyusunnya dalam sebuah disiplin ilmu secara utuh. Dan keluasan penge-

${ }^{6}$ Nasir Tamara dkk ed., HAMKA di Mata Hati Umat, Jakarta: Sinar Harapan, 1984, h. 5152.

${ }^{7}$ Samsul Nizar, Filsafat Pendidikan Islam, Jakarta: Ciputat Pers, 2002, h. 18-19. tahuan yang dimiliknya tentang Islam dan kepeduliannya terhadap umat Islam, yang diperolehnya berkat ketekunannya dan tanpa mengenal putus asa untuk senantiasa memper-dalam ilmu pengetahuan, telah diakui baik secara nasional maupun internasional. Hal ini dilihat dari beberapa anugerah yang diperolehnya. Samsul Nizar mendapatkan anugerah gelar Doktor Honoris Causa dari Universitas Al-Azhar Cairo Mesir atas jasa-jasanya dalam penyiaran agama Islam dengan menggunakan bahasa Indonesia yang indah. Kemudian pada 6 juni 1974 ia kembali mendapatkan gelar kehormatan dari Universitas Kebangsaan Malaysia pada bidang kesusasteraan, serta gelar professor dari Universitas Prof. Dr. Maestopo (Nizar, 2002: 41-44) ${ }^{8}$, yaitu sebutan untuk Universitas (beragama). ${ }^{9}$

\section{Karir Hamka}

Pada tahun 1924 dalam kunjungannya ke Jawa ia mendapatkan kesempatan untuk mengikuti kuliah umum yang diberikan oleh para pemimpin Muslim terkemuka. Pada akhir tahun 1952, ia memasuki dunia jurnalisme dengan mengirimkan artikel-artikel sehingga menghantarkannya dengan mendirikan jurnal Muhammadiyah pertama Chatibul Ummah sekembalinya ke Padang Panjang.

Pada tahun 1927 kepergiannya ke Medan dan Makkah telah mengenalkannya pada dunia Arab tidak hanya meningkatkan kemampuan bahasanya tetapi juga pengenalannya pada khazanah sastra Arab. Perkenalannya dengan Muhammadiyah membuat Hamka aktif di dalamnya, beberapa kali ia menjabat

\footnotetext{
${ }^{8}$ Ibid., h. 41-44.

${ }^{9}$ Nasir Tamara dkk., HAMKA, h. 199.
} 
sebagai pimpinan Muhammadiyah, sebagai Majelis Konsul Muhammadiyah di Sumatera Tengah (1934), pimpinan Muhammadiyah pada tahun (1942), dan anggota pusat Muhammadiyah hingga akhir hayatnya.

Pada tahun 1952 Hamka mendapatkan kesempatan untuk mengadakan kunjungan ke Amerika Serikat. Pada tahun 1958 ia menjadi anggota delegasi Indonesia untuk symposium Islam di Lahore. Dan dari Lahore ia meneruskan perjalanan ke Mesir, dan Doktor dari Universitas Al-Azhar dengan judul "Pengaruh Muhammad Abduh di Indonesia" yang menguraikan kebangkitan Islam di Indonesia.

Pada tahun 1955 ia terpilih menjadi anggota Majelis Konstituante mewakili partai politik Modernis Islam, Masyumi dan karir politiknya berakhir dengan dibubarkannya majelis ini leh presiden Soekarno. Selanjutnya pada tahun 1975 ia menjadi Ketua Majelis Ulama Indonesia dan terpilih kembali pada tahun 1980 yang akhirnya mengundurkan diri karena konflik politis dengan Menteri Agama.

Selama hidupnya Hamka terkenal sebagai ulama moderat dan pujangga, moderat karena ia dapat diterima oleh semua kalangan dengan pidatonya yang menejukkan hati dan mengorbankan semangat serta optimisme. Sebagai tokoh baru yang berani menentang dominasi adat terhadap agama di Minangkabau seperti adanya hubungan kekeluargaan yang bersifat matriarchal. Seorang ulama pujangga karena ia dikenal sebagai pengarang roman yang tidak sedikit karyanya berbentuk roman, selain itu ia juga meninggalkan lebih dari seratus karya monumentalnya adalah Tafsir Al-Azhar yang diselesaikannya selama berada dipenjara karena dianggap mengganggu rezim pemerintahan orde lama.

Menurut beberapa kajian yang telah dilakukan penulis salah satu latar belakang Hamka melontarkan beberapa pemikirannya dalam berbagai macam kajian adalah banyaknya pengalaman Hamka bergaul dengan beberapa orang besar seperti seperti H.O.S Tjokroaminoto, M. Natsir, K.H. Mas Mansur dan dari merekalah Hamka banyak mengetahui beberapa hal tentang pengetahuan beberapa filosof Barat seperti Plato dan Socrates, sehingga tidak heran jika dalam beberapa buku yang ditulis oleh Hamka banyak mengutip pendapat-pendapat para filosof Barat tersebut. Tumbuh dan kembangnya wawasan keintelektualan Hamka tidak bisa terlepas dari latar belakang pendidikan yang dilaluinya baik secara formal maupun non formal dan juga pengalaman hidup yang dilaluinya. Dinamika keintelektualan Hamka terbentuk dengan berdasarkan beberapa pengaruh, diantaranya: pertama, lingkungan keluarga, yang mana secara genetic adalah keluarga yang agamis yang secara tidak langsung telah membentuk konsistensi pemikiran Hamka terhadap Islam. Kedua, adalah lingkungan sosialnya, baik ketika ia berada di Minangkabau maupun di daerah perantauan Hamka yang telah mengisi kegersangan keintelektualannya dan menyalurkan potensinya dalam bidang jurnalistik. Ketiga, lingkungan organisasi keislaman (Muhammadiyah) yang sarat dengan nuansa pembaharuan serta dinamika berfikir secara kritis dan merdeka. Keempat, bacaannya yang luas 
dan mencakup berbagai macam kajian keilmuan, baik umum maupun agama. Beberapa hal tresebut sangat berperan dalam proses pembentukan atmosfer dinamika keintelektualan Hamka dan menghantarkannya sebagai sosok ulama-intelektual dan intelektual ulama pada zamannya yaitu paruh abad XX. Hamka meninggal dunia dengan memberikan segudang kontribusi diberbagai bidang, ia wafat di Jakarta pada tanggal 24 Juli 1981, dalam usia 73 tahun dan dikebumikan di Tanah Kusir Jakarta Selatan (Nizar, 2008: 45-46) ${ }^{10}$.

\section{Karya-karya Hamka}

Hamka sebagai seseorang yang berfikiran maju yang tidak hanya melakukan berbagai macam ceramah agama namun juga direfleksikannya melalui berbagai karya dalam bentuk tulisan. Orientasi pemikirannya luas meliputi berbagai macam disiplin ilmu (Nizar, 2008:46) ${ }^{11}$.

Sebagai salah satu seseorang yang terkenal di Asia tenggara yang pernah ditulis oleh Hamka dengan berbagai macam kajian, dan beberapa karyakaryanya yang terkenal adalah:

\section{a. Filsafat dan keagamaan}

1. Falsafah hidup, Pustaka Panji Masyarakat, 1950

2. Pelajaran Agama Islam. Bulan Bintang 1952

3. Pandangan Hidup Muslim. Bulan Bintang 1962

4. Lembaga Hidup. Pustaka Nasional 1999

5. Lembaga Hikmat. Bulan Bintang 1966

10 Samsul Nizar, Filsafat Pendidikan Islam, Jakarta: Ciputat Pers, 2002, h. 45-46.

11 Samsul Nizar, Filsafat Pendidikan Islam, Jakarta: Ciputat Pers, 2002, h. 46
6. Lembaga Budi. Pustaka Panjimas, 1983

7. Perkembangan Kebatinan di Indonesia. Yayasan Nurul Islam. 1980

8. Filsafat ketuhanan. Karunia, 1985

9. Tafsir al-Azhar Juz I-XXX. Pustaka Panjimas, 1986

10. Prinsip-prinsip da Kebijaksanaan Dakwah Islam. Pustaka Panjimas, 1990

b. Adat dan Kemasyarakatan

1. Adat Minangkabau Menghadapi Revolusi. Tekad, 1963

2. Islam dan Adat Minangkabau. Pustaka Panjimas, 1984

c. Kisah Perjalanan

1. Mengembara di Lembah Nil NV. Gapura, 1951

2. Mandi Cahaya di Tanah Suci. Tintamas, 1973

3. Merantau ke Deli. Bulan Bintang, 1977

d. Novel dan Roman

1. Teroris. Firma Pustaka antara, 1950

2. Di dalam Lembah Kehidupan. Balai Pustaka, 1958

3. Di Bawah Lindungan Ka'bah. Balai Pustaka, 1957

4. Tenggelamnya Kapal Van Der Wijk. Bulan Bintang, 1979

e. Sejarah Islam

1. Sejarah Umat Islam. Pustaka Nasional, 1950

2. Antara Fakta dan Khayal tuanku Rao. Bulan Bintang, 1974

f. Artikel Lepas

1. Lembaga Fatwa. Majalah Panji Masyarakat, No.6, 1972

2. Mensyukuri Tafsir Al-Azhar, Majalah panji Masyarakat, No. 317 
3. Muhammadiyah di Minangkabau, Makalah, Padang, 1975.12

\section{Penjara: Sengsara Membawa Berkah}

Perkembangan politik di Indonesia semakin buruk Hamka sebagai masyarakat dan ulama tak luput dari berbagi hasutan. Dia dituduh menyelenggarakan rapat gelap menyusun rencana pembunuhan Presiden Sukarno dan atas tuduhan tersebut Hamka ditangkap dan dijebloskan ke dalam penjara. $^{13}$ Tapi rupanya penjara ini memberikan hikmah tersendiri bagi Hamka. Seperti dikatakan Islamisis Belanda, Karel Steenbrink, kehidupan Hamka dalam penjara merupakan periode 'a time of grace', waktu yang berberkah. "Because now he had the time to write a full commentary of the Qur'an", demikian komentar Karel. ${ }^{14}$ Komentar Karel ini sangat tepat, karena Hamka sendiri dalam Tafsir al-Azhar-nya membeberkan pengalaman di penjara sebagai berikut :

“..... Tetapi di samping hati mereka yang telah puas, Tuhan Allah telah melengkapi apa yang disabdakan-Nya di dalam surat at-Taghabun ayat 11 . Yaitu bahwa segala musibah yang menimpa diri manusia adalah dengan izin Allah belaka. Asal manusia beriman teguh kepada Allah niscaya Allah akan memberikan hidayah ke dalm hatinya. Tuhan Allah rupanya

\footnotetext{
${ }^{12}$ Samsul Nizar, Filsafat, h. 252-256.

13 Dr. Yunan Yusuf, Corak Pemikiran Kalam Tafsir Al-Azhar, hlm. 50.

14 "Sebab sekarang dia (Hamka) mempunyai waktu untuk menulis sebuah tafsir al-Qur'an yang sempurna"; lihat: Karel Steenbrink, "Qur'an Interpretation of Hamzah Fansur (CA. 1600) and Hamka (1908-1982) : A Comparison", artikel ini dimuat dalam majlah Studia Islamika, Vol. 2, No.2, 1995, hlm. 81.
}

menghendaki agar terpisah dari anak isteri dua tahun, dan terpisah dari masyarakat, dapat saya pergunakan menyelesaikan pekerjaan berat ini, menafsirkan al-Qur'anulkarim. Karena kalau saya masih di luar, pekerjaan ayah ini tidak akan selesai sampai saya mati. Masa dua tahun telah saya pergunakan sebaik-baiknya. Maka dengan petunjuk dan hidayat Allah Yang Maha Kuasa, beberapa hari sebelum saya dipindahkan ke dalam tahanan rumah, penafsiran al-Qur'an 30 juzu' telah selesai. Dan semasa dalam tahanan rumah dua bulan lebih saya pergunakan pula buat menyisip mana yang masih kekurangan."15

Pengalaman dalam penjara ini rupanya sangat berkesan bagi Hamka, dan kesan itu dapat kita rasakan ketika dia menafsirkan ayat: "Karena sesungguhnya sesudah kesulitan itu ada kemudahan; sesungguhnya sesudah kesulitan itu ada kemudahan" (QS. Alam Nasyrah [94]: 5-6):

\begin{abstract}
"Kesulitan selalu beserta kemudahan. Yang sulit saja tidak ada. Yang mudah saja pun tidak ada. Dalam susah berisi senang, dalam senang berisi susah; itulah perjuangan hidup. Bahaya yang mengancam adalah menjadi sebab akal berjalan, pikiran mencari jalan keluar...Ternyata kesulitan adalah kejayaan dan keberuntungan yang tiada taranya." 16
\end{abstract}

15 Sulaiman Al-Kumayi, MA., $99 Q$ (Kecerdasaan 99): Cara Meraih Kemenangan dan Ketenangan Hidup Lewat Penerapan 99 Nama Allah, Buku Kedua (Jakarta: Hikmah, 2003), hlm. 171-172.

16 Prof. Dr. Hamka, Tafsir Al-Azhar, Juzu' XXX (Jakarta: Pustaka Panjimas, 1982), hlm. 
Hamka sendiri tidak merasa dendam kepada orang-orang yang telah melakukan fitnah yang menyebabkan ia harus mendekam dalam penjara. "Adapun kepada mereka itu yang telah menyusun fitnah itu, atau yang telah menumpangkan hasadnya dalam fitnah orang lain, setinggi-tinggi yang dapat ayah berikan hanya maaf saja", demikian Hamka. ${ }^{17}$ Di lain pihak, selama penahanan ini, selain menyelesaikan tafsirnya, Hamka juga mendapat kesempatan di malam hari untuk salat tahajud, mengkhatamkan Al-Quran lebih dari 100 kali. Ia juga membaca bukubuku Tasawuf, Tauhid, Filsafat Agama, Hadits-hadits Rasulullah, Tarikh pejuang-pejuang Islam dan kehidupan ahli-ahli tasawuf dan ulama, jalan akhirat ia pelajari dan resapkan. ${ }^{18}$ Dengan demikian selama dalam penjara merupakan masa-masa untuk menambah ilmu pengetahuan dan meresapkan ajaran agama ke dalam jiwa.

Selesai dari tahanan, tahun 1975 Hamka diminta menjadi Ketua Umum MUI. Pengangkatan Ketua Umum MUI ini oleh Nurcholish Madjid sebagai bukti dari jiwa independen Buya Hamka. Kita mengetahui betapa kontraversilnya gagasan dan pembentukan organisasi itu. Sampai saat inipun sisa-sia kontraversi itu masih terasa di masyarakat. Karena gagasan tentang lembaga itu erat berkaitan dengan pemerintah, maka tak dapat lagi dihindarkan adanya penilaian kurang positif kepada Buya Hamka, malah sempat pula terdengar tuduhan

\footnotetext{
17 Ibid., hlm. 54.

18 Ibid., hlm. 55.
}

kepadanya sebagai "oportunis". ${ }^{19}$ Tetapi pada bulan Mei 1981 Hamka meletakkan jabatannya sebagai Ketua MUI akibat fatwanya yang berlawanan dengan kebijakan pemerintah mengenai perayaan Natal bersama. Sebagai aktivis Muhammadiyah, Hamka tetap duduk sebagai penasehat Pimpinan Pusat Muhammadiyah.

Dua bulan setelah pengunduran dirinya sebagai ketua umum MUI. Ia masuk rumah sakit karena serangan jantung yang cukup kuat selama lebih kurang satu minggu tepatnya pada tanggal 17 Juli 1984 Hamka berbaring di rumah sakit Pertamina Pusat Jakarta yang ditangani oleh para dokter ahli. Mereka sudah berusaha keras untuk menyelamatkan ulama besar itu, tetapi Tuhan berkehendak lain. Akhirnya dia berpulang ke rahmatullah dengan tenang pada tanggal 24 Juli 1981 ketika kaum Muslimin bersiap-siap menunaikan salat Jum'at. Jenazahnya dimakamkan di Taman Pemakaman Umum (TPU) Tanah Kusir Kebayoran Lama Jakarta dengan diantar ribuan umat Islam. ${ }^{20}$

\section{Konsep Akidah Hamka}

Telah penulis sebutkan bahwa istilah akidah, tauhid dan keimanan/kepercayaan adalah sama. Hamka mengartikan aqidah atau tauhid adalah kepercayaan kepada Allah Yang Maha

${ }^{19}$ Nurcholish Madjid, "Buya Hamka, Profil Seorang Ulama Berjiwa Independen", dalam Solichin Salam, Kenang-kenangan 70 Tahun Buya Hamka, hlm.254.

${ }^{20}$ Haji Rusydi, dkk., Perjalanan Terakhir Buya Hamka (Jakarta: Pustaka Panjimas, 1981), hlm, hlm.21. 
Esa. ${ }^{21}$. Kepercayaan kepada Allah SWT tersebut menurut Hamka (1965) dalam bukunya "Pelajaran Agama Islam" mencakup enam kepercayaan (enam rukun iman), yaitu kepercayaan kepada yang gaib, kepercayaan kepada kitabkitab, kepercayaan kepada rasul-rasul, kepercayaan kepada hari kiamat, kepercayaan kepada taqdir (qada' dan qadar).

Hamka menjelaskan bahwa tauhid/akidah adalah ajaran Islam yang paling pokok, mengakui akan ke Esaan Tuhan, satu kekuasaan tertinggi, satu pengatur alam raya, tidak bercabang dan tidak pecah. Selain Allah SWT adalah makhluk atau benda belaka. ${ }^{22}$

Akidah atau tauhid adalah rohnya agama Islam dan jauhar intisarinya da pusat dari seluruh peribadatannya. Laksana tanah kering. Menjadi suburlah dia kalau telah disiram oleh air tauhid atau aqidah. Akidah (tauhid) sangat besar pengaruhnya menggembleng jiwa sehingga kuat dan teguh. Kebebasan jiwa, kemerdekaan pribadi, dan hilangnya rasa takut menghadapi segala kesukaran hidup, keberanian menghadapi segala kesulitan, sehingga tidak berbeda diantara hidup dengan mati, asal untuk mencari ridla Allah SWT. ${ }^{23}$

Hamka menjelaskan bahwa pengertian akidah atau tauhid mengandung dua aspek tauhid, yaitu tauhid rububiyyah dan tauhid uluhiyyah, menyangkut pengertian tauhid secara teoritis dan praktis.

21Hamka, Pelajaran Agama Islam, Jakarta: Bulan Bintang,1956, h. 25-26.

${ }^{22}$ Hamka, Tafsir Al-Azhar, Juz I, Jakarta: Pustaka Panjimas, 1982, h. 258.

23 Hamka, Pelajaran, h. 61-62
Tauhid rububiyyah yaitu mengakui bahwa di dunia ini hanya ada satu Tuhan, yaitu Allah SWT. Sedangkan tauhid uluhiyyah adalah menyembah, beribadah dan memuji-Nya. ${ }^{24}$

Menurut Hamka inti ajaran akidah/tauhid adalah memerdekakan manusia dari perbuatan syirik ${ }^{25}$. Dengan demikian, seluruh aktifitas manusia selama hidup ini bertujuan untuk mencari atau mengusahakan agar semua aktifitasnya itu mendapatkan ridla dari Tuhan Yang Maha Esa. Semua manusia berkedudukan sanam di mata Tuhan. Tidak ada perbedaan warna kulit, atau diskrimasi ras dan tidak ada perbedaan karena keturunan. Makhluk paling mulia di sisi Allah SWT adalah mereka yang paling bertaqwa kepada-Nya. Hak dan kewajiban semua manusia sama, tidak dibeda-bedakan. Setiap orang harus berusaha meningkatkan kualitas imannya. Setelah itu, berusaha meningkatkan kualitas imannya. Setelah itu, berusaha meningkatkan kualitas imana dalam lingkungannya dari sekup yang paling kecil (keluarga), meluas hingga tetangga, kampong, negeri, sampai ke tingkat dunia.

Jiwa manusia adalah sempurna. Manusia adalah makhluk yang dijadikan oleh Allah SWT untuk menjadi khalifahNya di muka bumi ini. Oleh karena itu, maka hubungan tiap manusia dengan Allah SWT hendaklah langsung. Jiwa yang dipenuhi dengan perasaan tauhid adalah jiwa yang merdeka. Apabila manusia telah mempertuhankan yang lain, sedang yang lain itu hanyalah makhluk/benda belaka, maka manusia sendiri yang membawa jiwanya jadi

\footnotetext{
${ }^{24}$ Hamka, Tafsir Al-Azhar, Juz XV, h. 39.
}

${ }^{25}$ Hamka, Tafsir Al-Azhar, Juz IX, h. 213 
budak orang lain. Mempersekutukan yang lain dengan Allah SWT adalah aniaya yang paling besar. Sebab tujuan hidup bisa jadi pecah berderai dan manusia sendiri pun jadi berpecahpecah karena syirik.

Dengan demikian maka akidah merupakan pokok kepercayaan, artinya haram mempersekutukan-Nya dan wajib mentauhidkan-Nya. Kemusyrikan yang haram itu bukan hanya menyembah berhala. Bahkan jika ada tempat hidup, tempat berlindung diri, serta tempat memohon selain Allah, maka itu juga musyrik. Sehingga meskipun beramal baik, akan tetapi bukan karena Allah SWT, melainkan semata-mata mencari penghargaan manusia, itu disebut riya', dan riya' itu merupakan syirik khafi (mempersekutukan Allah SWT secara halus). ${ }^{26}$

\section{Hamka: Pendidikan Akhlak}

\section{Akhlak}

Sebelum dipaparkan pemikiran Hamka tentang pendidikan akhlak, akan penulis paparkan tentang akhlak menurut Hamka.

Hamka $^{27}$ mneyebutkan bahwa akhlak adalah sesuatu yang tertanam dalam jiwa manusia, atau suatu kondisi jiwa seseorang yang dapat memunculkan suatu tingkah laku baik atau buruk sesuai dengan kondisi jiwa tersebut. Ia menggunakan istilah akhlak dengan budi.

Ia menyebutkan bahwa tingkah laku manusia berasal dari jiwanya yang telah melalui sebuah proses perjuangan antara akal dan nafsu manusia berasal dari jiwanya yang telah melalui sebuah

\footnotetext{
${ }^{26}$ Hamka, Tafsir Al-Azhar, Juz VIII, h. 102

${ }^{27}$ Hamka, Falsafah Hidup, Jakarta: Pustaka Panjimas, 1986, h. 94
}

proses perjuangan antara akal dan nafsu yang disebut dengan keutamaan. Lebih lanjut ia menyebutkan:

Menurut keterangan yang lekas difahami, ialah keutamaan sesudah terjadi perjuangan batin, hawa nafsu dengan akal yang waras. Hawa nafsu mengajak mengerjakan yang memberi mudharat dan akal mengajak mengerjakan yang manfaat itu sebelum terjadi perjuangan. Bila mana akalnya menang, dipilihnya yang manfaat, jadilah ia seorang ia seorang yang utama. Kalau terjadi sebaliknya, jadilah ia seorang yang durjana. Seorang yang utama senantiasa membiasakan mengerjakan yang disuruh akalnya, mula-mula dengan perjuangan, lama-lama menjadi kebiasaan. ${ }^{28}$

Menurut Hamka akhlak/tingkah laku manusia erat hubungannya dengan beberapa unsure yang terdapat dalam diri manusia, jika seseorang dapat mengetahui hal-hal yang berpengaruh atau dapat mempengaruhi diri maka seseorang tersebut akan dapat mengetahui akhlak yang timbul dalam perilakunya, dengan adanya hal ini maka sesuatu atau akhlak yang buruk yang ada dalam diri seseorang hendaknya ia berusaha untuk memperbaikinya. Hamka dalam hal ini juga mengkatagorikan akhlak dalam dua hal yaitu akhlak yang terpuji (budi pekerti yang mulia) dan juga akhlak yang tercela atau akhlak yang buruk.

Menurut Hamka, dalam agama Islam akhlak yang mulia merupakan sutu tujuan ditegakkannya kemuliaan akhlak. Bahkan keutamaan atau akhlak yang mulia menjadi seruan dalam agama

28Ibid., h. 81 
Islam. Ia mendasarkan pada sebuah hadits yang mengatakan:

"Sesungguhnya setengah dari pada akhlak orang yang mukmin, ialah kuat menjalankan agama, teguh di dalam lemah lembutnya, beriman di dalam keyakinannya, loba akan ilmu pengetahuan, belas kasian di dalam satu ketelanjuran, pemaaf di dalam ilmu, berhemat di dalam kaya, berhias di dalam kesempitan, berpantang loba tamak, berusaha pada yang halal, berbuat kebajikan pada ketetapan pendirian, tangkas di dalam petunjuk, mengendalikan diri di dalam syahwat, belas kasihan kepada orang yang payah."29

Beberapa hal yang mendorong seseorang untuk senantiasa berbuat kebaikan, menurut Hamka yang mengutip pendapat al-Ghazali menyebutkan dalam tiga perkara:

1. Karena adanya bujukan atau ancaman dari orang lain.

2. Mengharap pujian atau karena takut mendapat cela dari orang lain

3. Karena kebaikan dirinya (dorongan hati nurani) yang senantiasa untuk melakukan perbuatan yang mulia. ${ }^{30}$

Lebih lanjut Hamka menjelaskan tentang hal-hal yang mendorong seseorang untuk berbuat kebaikan untuk kehidupan akhirat dengan tiga macam perkara:

1. Mengharap pahala dan surga dan takut akan azab neraka

2. Mengharapkan pujian dari Allah SWT dan takut akan celanya

3. Mengharapkan ridla Allah SWT semata. ${ }^{31}$

\footnotetext{
${ }^{29}$ Ibid., h. 95.

${ }^{30}$ Ibid., 90-91.

31 Ibid., h. 91.
}

Sedangkan hal-hal yang dapat menghambat seseorang untuk berbuat kebaikan adalah:

1. Adanya penghambat, hal ini disebabkan karena adanya halangan yang disebabkan karena sakit, kemiskinan dan lain-lain.

2. Karena taksir atau kelalaian. Hal ini disebabkan oleh empat perkara, yaitu: Pertama, karena tidak dapat membedakan yang baik dan buruk, yang haq dan batil. Kedua, mengetahui hal yang baik dan buruk tetapi tidak bisa mengerjakan suatu hal kebaikan, sehingga ia menganggap bahwa suatu kejahatan adalah hal yang baik. Ketiga, kesalahan pendidikan yang diterima sejak kecil yang memberikan anggapan bahwa yang jahat itu baik dan yang baik itu jahat. Keempat, kebusukan hati yang beranggapan bahwa berbuat kebaikan merupakan suatu hal yang sia-sia. ${ }^{32}$

Menurut Hamka akhlak yang mulia timbul karena adanya pengaruh agama yang telah meresap ke dalam jiwa, pengaruh agama yang kuat dan semakin dalam akan terpancar dengan sifat lemah lembut seseorang. Lebih lanjut ia mengatakan bahwa budi pekerti yang mulia tidak timbul kalau tidak dari sifat keutamaan. Keutamaan tercapai dari perjuangan, berebut-rebutan kedudukan antara akal dan nafsu. ${ }^{33}$

Dalam kaitannya dengan budi pekerti yang mulia, Hamka mengatakan, "Budi utama itu berhubungan dengan perasaan hati, bertambah dalam perasaan itu bertambah tinggilah derajat keutamaan dan bertambah pula

\footnotetext{
${ }^{32}$ Ibid., h. 90-92.

33Ibid., h. 92.
} 
rasa wajib, karena keutamaan adalah pangkal dari budi." 34 Ia menambahkan bahwa ciri-ciri orang yang berbudi adalah:

1. Tidak banyak bicara sesuatu yang tidak bermanfaat

2. Menjauhkan diri dari perbuatan yang tercela

3. Mudah memberikan pujian kepada orang lain, dan

4. Tidak cepat menuduh orang lain. ${ }^{35}$

Hamka membagi keutamaan ke dalam empat kategori, yang ia sebut juga sebagai upaya untuk memperoleh kesehatan jiwa, yaitu:

1. Syaja'ah, yaitu berani pada akebenaran dan takut pada kesalahan (Hamka, 1983: 115) ${ }^{36}$. Ia merupakan sesuatu yang digunakan untuk membangkitkan keberanian menempuh sebuah kesulitan untuk kemaslahatan hidup. Perilaku yang timbul dari adanya sifat syaja'ah oleh Hamka disebut dengan teguh, tangkasm perwira, kesatria, berani melawan bahaya, dan teguh dalam pendirian.

2. Iffah,pandai menjaga kehormatan batin (Hamka, 1983: 115) ${ }^{37}$, kemampuan mengatur dan menahan diri sendiri untuk tidak terjerumus kepada sesuatu yang mendatangkan bahaya, dan perilaku yang timbul dari sifat ini adalah qana'ah dan tawadlu'.

3. Hikmah, tahu rahasia dari pengalaman kehidupan. ${ }^{38}$

${ }^{34}$ Ibid., h. 93.

35 Hamka, Tasauf Modern, Jakarta: Pustaka Panjimas, 1983, h. 125.

${ }^{36}$ Hamka, Tasauf Modern, Jakarta: Pustaka Panjimas, 1983, h. 115.

${ }^{37}$ Ibid., h. 115.

38 Hamka, Tasauf Modern, h. 115.
4. 'Adil, yaitu meletakkan sesuatu pada tempatnya dan memberikan barang pada yang empunya. 39 'Adil merupakan perangai mulia dari akal budi yang mengendaikan diri seseorang dari marah, syahwat, dan akal budi.

Hal-hal yang dapat dilakukan dalam upaya menjaga kesehatan jiwa adalah:

1. Bergaul dengan orang-orang beriman, pergaulan akan mempengaruhi cara berfikir, membentuk kepercayaan dan keyakinan.

2. Membiasakan pekerjaan berfikir, hal ini dilakukan untuk menjaga kesehatan jiwa agar otak tidak dibiarkan kosong dengan membiasakan berfikir sekalipun dalam masalah kecil.

3. Menjaga syahwat dan kemarahan. Agar batin sehat, hendaklah didukung jangan sampai terpengaruh oleh kekuatan syahwat dan marah.

4. Tadbir, menimbang sebelum mengerjakan (bekerja dengan teratur). Sebelum mengerjakan suatu pekerjaan, hendaknya timbang dahulu manfaat dan madharatnya, akibat dan natijahnya.

5. Menyelidiki aib diri sendiri. Orangorang takut cacat dirinya. Manusia tidak ingin kerendahan, semua suka kemuliaan. Tetapi jarang orang yang tahu akan aibnya, dan tidak yahu akan aib diri, adalah aib yang sebesar-besarnya. ${ }^{40}$.

Mengenai akhlak yang buruk atau tingkah laku yang buruk, menurut Hamka harus ditinggalkan untuk mendapatkan kehidupan yang baik. Adapun dalam menguraikan akhlak yang buruk,

\footnotetext{
${ }^{39}$ Hamka, Falsafah Hidup, h. 84.

${ }^{40}$ Hamka, Tasauf Modern, h. 106-110.
} 
Hamka mengutip pendapat Muhyiddin Ibnu 'Arabi, yang meliputi:

1. Fujur, yaitu terlarut dan selalu mengikuti hawa nafsu, dan selalu mengikuti kehendak-kehendak yang buruk.

2. Syarah, kecintaan yang berlebih terhadap harta benda (tamak)

3. Tabazzul, tidak mengetahui harga diri, dan sering bergaul dengan orang-orang yang tidak bermoral atau rendah akhlaknya.

4. Safah, cepat marah dan mudah mencaci maki orang lain, terlalu cepat mengambil keputusan yang dapat menyengsarakan orang lain.

5. Kharq, sering membicarakan kepentingan sendiri dan hanya mau didengar oleh orang lain. Ibarat sebuah pepatah yang mengatakan beriak tanda tak dalam.

6. Qasawah, memiliki sifat benci dan dendam, tidak mempunyai rasa belas kasihan.

7. Khaddar,sering mengingkari janji

8. Khianat, mengabaikan amanat yang diberikan oleh orang lain, dan sering memutar balikkan fakta atau perkataan orang lain.

9. Membuka rahasia, tingkah laku ini adalah menyimpan rahasia orang lain. Yang termasuk dalam tingkah laku ini adalah namimah yaitu sering menyebarkan berita bohong

10. Takabbur, sering memuji diri sendiri, merasa dirinya yang paling benar dan berjasa, dan ia sering menganggap orang lain kurang.

11. Khabats, berniat jahat kepada orang lain, dan melakukan sesuatu yang dapat merugikan orang lain. Termasuk dalam kategori akhlak ini adalah haqad yag berarti dendam
12. Bakhil, yaitu selalu menganggap bahwa harta adalah tujuan dalam hidup, ia enggan mengeluarkan harta untuk kemaslahatan umum, terlebih ia menyiksa diri dengan sesuatu yang hina hanya untuk harta.

13. Jubun, takut menghadapi tanggung jawab dan tidak berani menanggung akibat

14. Hasad, dengki, sakit hati dengan kebahagiaan yang didapat oleh orang lain dan bahagia ketika orang lain berada dalam kesedihan

15. Jaza', adalah sifat antara kharq dan jubun, yaitu tidak berani menghadapi kesulitan

16. Sagirul Himmah, tidak berjiwa besar dan tidak mempunyai cita-cita yang tinggi

17. Al Jaur, berlebih-lebihan dalam segala hal, tingkah laku, menghambur-hamburkan uang (boros) dan melakukan sesuatu yang tidak sesuai dengan waktu dan tempatnya

Hamka mengemukakan tentang beberapa cara yang dapat dilakukan untuk dapat mengobati kerusakan akhlak yang terjadi di masyarakat yang ia nyatakan dengan: "untuk mengobati akhlak yang rusak dipakailah dua cara: pertama yang positif, kedua yang negatif".

Yang positif ialah memperbaiki dalam masyarakat seumpama mendirikan sekolah-sekolah dan memperbaiki pemuda-pemuda, mengatur susunan pengajaran, memberantas pemabukan dan pelacuran, menyediakan rumahrumah pemeliharaan anak yatim, orang miskin, supaya jangan ada orang gelandangan, menyensor film cabul, 
buku-buku porno dan lain-lain. Yang negatif ialah penangkapan atas yang melanggar, tuntutan di muka hakim, penahan dan hukuman

Hamka memandang akhlak sangat penting bagi umat manusia, mengenai pentingnya akhlak bagi kehidupan manusia Hamka menyatakannya dalam beberapa kebutuhan, yaitu:

Pertama, mendapatkan kemuliaan. Kemuliaan menurut pandangannya merupakan suatu gambaran batin dan telah mencapai kesempurnaan dan keutamaan budi. Orang yang disebut mulia adalah orang yang dapat mengendalikan hawa nafsu, serta menegakkan budi pekerti yang mulia. Hamka menyatakan, “orang yang patut disebut bangsawan ialah yang menang di dalam melawan dan menghadapi nafsunya yang jahat, mengengakkan budi pekerti yang mulia". Hamka dengan mengutip pendapat Syeikh Muhammad Abduh, membagi kemuliaan menjadi dua, yaitu kemuliaan hidup dan kemuliaan jasa. Kemuliaan hidup adalah kemuliaan akhlak di dalam pergaulan karena dapat menghormati orang lain. Sedang kemuliaan jasa terbagi dua, yaitu jasa lahir yang dapat dilihat dan jasa batin yang dapat dipikir. Dari dua kemuliaan itu, kemuliaan jasa lebih tinggi setingkat dari kemuliaan hidup. Kemuliaan hidup tidak lama usianya, dia hilang bersama diri yang empunya, sedangkan kemuliaan jasa kekal dari zaman ke zaman. (Hamka, 1968: 222223) $)^{41}$

Kedua, bekal kehidupan di masa depan, sebagaimana diungkapkan oleh Achmad Sathari berdasarkan penga- lamannya bersama Hamka bahwa: menurutnya generasi muda yang hanya dipompa dengan ilmu pengetahuan saja tanpa disertai dengan akhlak, hanya akan melahirkan pelacur-pelacur intelektual, dan perilaku yang secular. Berbekal akhlak saja itu pun belum cukup. Akhlak tanpa disertai dengan ilmu, akan melahirkan manusia buda, yang selalu menjadi objek keadaan.

Menurut Hamka, bahwa generasi muda harus berbekal keduanya: akhlak dan ilmu. Dengan demikian akhlak dalam hal ini teramat penting bagi para remaja sebagai bekal kehidupannya dimasa depan sebagai suatu penuntun dan petunjuk untuk dapat menjalani kehidupan masa depannya dengan baik sehingga tidak terjerumus dan larut dalam perkembangan zaman. ${ }^{42}$

Sebagai sarana dakwah. Akhlak yang mulia dalam Islam juga dibutuhkan dalam rangka dakwah atau mengajak seseorang ke dalam ajaran agama Islam. Antara ilmu dan akhlak harus seimbang, banyaknya ilmu tanpa adanya akhlak akan membawa celaka. Sedangkan akhlak tanpa berisikan ilmu tidak juga memberikan manfaat kepada masyarakat. 43

Untuk mendapatkan kebahagiaan. Menurut Hamka, sebagaimana dijelaskan oleh Nizar (2008: 166) seseorang tidak akan mendapat makna kebahagiaan tatkala kesehatan jiwa, akal dan jasmaniah telah dimilikinya. Keutamaan kesehatan tersebut akan memancar pada dirinya nur Ilahi yang terlihat melalui cerminan akhlak yang mulia, terbuka wawasan pikiran dan
${ }^{42}$ Nasir Tamara dkk ed., HAMKA, h. 267.

${ }^{43}$ Hamka, Tasauf Modern, h. 159. 
senantiasa berupaya mencerdaskan potensi akal. ${ }^{44}$,

\section{Hubungan Pendidikan Akidah dan Pendidikan Akhlak}

Kaitannya dengan pembahasan ini, di satu sisi Hamka menyatakan bahwa akidah atau tauhid adalah ruhnya agama Islam dan pusat dari seluruh peribadatan. Akidah sangat kuat pengaruhnya terhadap perilaku seseorang dalam menghadapi kehidupan. ${ }^{45}$ Di sisi lain, ia menyatakan bahwa akhlak atau keutamaan terjadi sesudah terjadinya perjuangan batin, antara hawa nafsu dengan akal sehat. Hawa nafsu mengajak mengerjakan yang member mudharat dan akal mengajak mengerja-kan yang manfaat. Bilamana akalnya menang, dipilihnya yang manfaat, jadilah ia seorang yang utama. Kalau terjadi sebaliknya, jadilah ia seorang yang durjana. Seorang yang utama senantiasa membiasakan mengerjakan yang disuruh akalnya. Mula-mula dengan berjuang, lama-lama menjadi kebiasaan. ${ }^{46}$

Jadi, akhlak mulia terwujud atas perjuangan, berebut-rebutan kedudukan antara akal dan nafsu. Mula-mula ditempuh dengan berjuang. Setelah itu diajar, dibiasakan, sehingga menjadi perangai tetap. ${ }^{47}$

Kaitannya dengan pembahasan ini, penulis kemukakan dua hadits yang telah dikutip oleh Hamka sebagai berikut:

"Sesungguhnya setengah dari pada akhlak orang yang mukmin, ialah kuat menjalankan agama, teguh di dalam lemah lembutnya, beriman di dalam h. 166.

${ }^{44}$ Samsul Nizar, Filsafat Pendidikan Islam,

${ }^{45}$ Hamka, Pelajaran Agama Islam, h. 61.

${ }^{46}$ Hamka, Falsafah Hidup, h. 81.

${ }^{47}$ Ibid., h. 92 ketelanjuran, pemaaf di dalam ilmu, berhemat di dalam kaya, berhias di dalam kesempitan, berpantang loba tamak, berusaha pada yang halal, berbuat kebajikan pada ketetapan pendirian, tangkas di dalam petunjuk, mengendalikan diri didalam syahwat, belas kasihan kepada orang yang payah".

"sesungguhnya orang yang mukmin dari pada hamba Allah, tidak berdendam kepada orang banci, tidak berdosa karena cinta, tidak menyianyiakan barang yang dipertaruhkan, tidak pernah hasad, tidak pernah mencela, tidak pernah memaki. Mengakui akan yang benar meskipun tidak diminta tidak suka mempersanda-sandakan gelaran. Di dalam sembahnyang dia khusuk, segera ia mengeluarkan zakat, tenang walau disekitarnya rebut, tunduk di dalam kemegahan, syukur dan mencakupkan apa yang ada, tidak mendakwahkan apa yang bukan kepunyaannya, tidak terlanjur lantaran marah, tidak dipengaruhi oleh kebakhilan, mengerjakan yang makruf, bergaul dia dengan manusia supaya dia beroleh ilmu, lemah supaya tetap dan teguh, sehingga dia teraniaya dan dimungkiri orang, namun dia tetap dan teguh, sehingga Tuhan Yang Rahman sendiri yang akan membelanya". ${ }^{48}$

\section{E. Penutup}

Berdasarkan paparan di atas, maka dapat diketahui bahwa menurut Hamka, pendidikan akidah memiliki hubungan yang sangat erat dengan pendidikan akhlak. Akidah menjadi landasan bagi pelaksanaan akhlak. Perbuatan yang didsari dan djiwai oleh akidah akan

48Ibid., h. 95-96. 
menimbulkan perbuatan yang terarah, terencana, sehingga terjaga dari perbuatan syirik.

Akidah yang benar dan kuat akan memunculkan akhlak yang mulia dan kuat. Semua yang dilakukan merupakan cerminan dari kekuatan akidah, sehingga perilaku yang dilakukan merupakan perilaku yang benar dan ikhlas, mencerminkan perilaku ibadah kepada Allah, sesuai dengan penjelasan Allah dalam Kitab Suci-Nya:

Dan Aku tidak menciptakan jin dan manusia melainkan supaya mereka beribadah kepada-Ku (QS. al-Żariyat: 56).

Sebaliknya, akidah atau iman yang tidak ikhlas dan lemah akan memunculkan perilaku yang tidak benar, tidak ikhlas dan tidak mencerminkan perilaku ibadah. Perilaku ini akan merugikan diri sendiri, dan kadang juga merugikan orang lain dan masyarakat. []

\section{DAFTAR PUSTAKA}

Al-Banna, Hasan, Akidah Islam, terj. M. Hasan Baidaie, Bandung: AlMa'arif, 1983.

Amin, Ahmad, Etika Islam (Ilmu Akhlak), terj. Farid Ma'ruf, Jakarta: Bulan Bintang, 1983.

Anshari, Endang Saifuddin Wawasan Islam, Pokok-pokok Pikiran tentang Paradigma dan Sistem Islam, Jakarta: Gema Insani, 2004.

Hamka, Falsafah Hidup, Jakarta: Pustaka Panjimas, 1986.

Hamka, Pelajaran Agama Islam, Jakarta: Bulan Bintang,1956.

Hamka, Tafsir Al-Azhar, Juz I-XXX, Jakarta: Pustaka Panjimas, 1982
Hamka, Tasauf Modern, Jakarta: Pustaka Panjimas, 1983.

Nizar, Samsul, Filsafat Pendidikan Islam, Jakarta: Ciputat Pers, 2002.

Rajab, Hadarah, Akhlak Sufi: Cermin Masa Depan Umat, Jakarta: AlMawardi Prima, 2004.

Syaltout, Mahmud, Islam sebagai Akidah \& Syariah, Jilid I terj. Bustami S. Gani dan B. Hamdani Ali, Jakarta: Bulan Bintang, 1983.

Tamara, Nasir, HAMKA di Mata Hati Umat, Jakarta: Sinar Harapan, 1984. 